\title{
The Biology of Balanus balanoides. IV. Relation to Environmental Factors.
}

\author{
By \\ Hilary B. Moore, Ph.D., \\ Marine Biological Laboratory, Plymouth.
}

With 11 Figures in the Text.

Contents.

General
Relation of Vertical Distribution to Wave-Exposure
Relation of Density of Population to Wave-Exposure

\section{GeneraL.}

THE most detailed work on the distribution of Balanus balanoides and its relation to its habitat, so far as European seas are concerned, is that. of Fischer-Piette and of Hatton. In Hatton and Fischer-Piette (1932) an account is given of four localities of progressive degrees of wave-exposure, in the neighbourhood of St. Malo, together with the density of population of the barnacles at four different levels at each locality, and their rate of growth and mortality. In Fischer-Piette (1928 and 1932) a further account is given of the distribution of this species along the French coasts of the Channel, and the variations in its zonation and abundance in so far as these can be related to environmental conditions. In Fischer-Piette (1929) a detailed description is given of the distribution of this and other 
species up the estuary of la Rance, in relation to the wide range of physical and chemical conditions found there, from which it has been possible to give the limiting values for some of these factors. Finally, in FischerPiette (1934), the account of the distribution of this species along the Channel coasts is extended to include the south coast of England, and the north coast of Cornwall.

In earlier papers of the present series (Moore, 1934, 1935) an account has been given of the growth of the shell and the seasonal changes in the soft parts of B. balanoides growing at various tidal levels in Port Erin Bay, in the Isle of Man, this locality being typical of a fairly exposed coast. The present paper relates the growth, maturity, etc., of the barnacles to certain of the environmental factors, and as one of the chief of these, after tidal level, is the degree of exposure to wave-action, an attempt has been made to give some numerical value to this factor.

After discussion with Mr. J. R. Bruce, the following factor has been chosen as probably representing the closest approximation permissible in the present state of our knowledge. In the absence of a direct measure of the force of incident waves, a theoretical value might be arrived at from a knowledge of the amount and force of the winds incident on the locality in question, and the forces of waves which they would produce. The angular aperture of the locality may be determined, and in addition the number of days in the year with winds of measured direction and force are frequently available. Further, the wave-raising power of a given wind is known, but two factors are at present undetermined. These are the exact effect of a shallow bottom near the shore, and the relation between "fetch," or the distance over which the wind has acted on the water, and the size of the wave produced when the wind is less than gale force and the distance is less than the amount necessary to produce the maximum wave possible for the wind in question. Lacking the full data required for a calculation of the desired factor, we have chosen a factor for waveaction which is defined as the number of days per hundred days in which any wind blows into the exposed aperture of the locality in question, this opening being the seawards aperture measured at a distance of half a mile. Thus, if the year's wind were uniformly distributed, a locality open through $180^{\circ}$ would have an exposure factor of 50 .

Such a factor is admittedly far from perfect in many respects, but it seems adequate for comparing a series of localities such as those used in the Isle of Man. And it is to be hoped that in the future a more perfect measure may be produced.

Fischer-Piette (1932) chose four degrees of wave-exposure which he defined as follows :--

Très battu.

Peu battu, mais encore dépourvu de Fucacées. 
Abrité et couvert de Fucacées.

Très abrité.

The species and abundance of the Fucaceæ present is a useful guide to exposure, but clearly some more physical measure is desirable.

The four localities worked in the Isle of Man are as follows :-

A. Inner Pier, Port St. Mary. Exposure factor 0.

Situated on the vertical face of the inner side of the pier, about 25 feet from the seaward end, and having its lowest zone about 7 feet above a bottom of mud and gravel. The surface of attachment is limestone. The locality faces west and is not exposed at all to the open sea.

B. Alfred Pier, Port St. Mary. Exposure factor 8.

Situated on the vertical face of the inner side of the Alfred Pier, about 800 feet from the seaward end. The surface of attachment is dressed limestone blocks faced with cement except where this has flaked off in the lowest zone. The bottom, two to ten feet below the lowest zone, is rocks and coarse shingle. The locality faces north-west, and has a slight exposure over a distance of more than half a mile of water, though not to really open sea.

\section{Dub Reef, Port Erin. Exposure factor 30.}

This is the locality where most of the previous work has been done (Moore, 1934, etc.). It is the vertical face of a gulley in the rocks on the east side of Port Erin Bay. The surface faces roughly south, and has a considerable lateral exposure to the west to the open sea. The substratum is Manx slate, and the bottom, below the barnacles, is rocks.

D. Outside Bradda Head. Exposure factor 55.

This was the most wave-exposed locality available. It is completely open to the sea from NNE to SSW, and faces west. The substratum is Manx slate, and the bottom shingle and rocks. There is an abrasion zone of clean rock surface for about a metre above the shingle, so care had to be taken to avoid this in choosing a traverse.

Levels throughout this paper are referred to ordnance mean sea level for the Isle of Man. In the case of Port Erin and the two Port St. Mary localities the levels of the barnacle patches were referred by tape to a datum kindly fixed for me by Mr. J. R. Bruce. This was not possible outside Bradda, and the necessary measurements were made from the level of the water on a very calm day, simultaneous measurements being made on a tide staft in Port Erin Bay. High water of mean neap tides at Port Erin is approximately four feet above mean sea level, and high water of mean and extreme spring tides respectively eight feet six inches, and ten feet above.

The material was obtained from a traverse down the shore in each 
locality, worked in June-July, 1933, with additional samples taken at other times for details of the condition of the gonads, etc. Samples were taken at successive levels, and the various year groups were distinguished as far as possible (Parke and Moore, 1935). A selection from these was then sorted into size groups, decalcified, dried and weighed (as in Moore, 1935, p. 264), and the results obtained are given in Tables I to IV.

\section{Relation of Vertical Distribution to Wave-Exposure.}

The extreme upper and lower limits of distribution of barnacles on the open rock surface are shown in Figure 1, plotted against the wave-exposure of the localities. Young spat can sometimes establish themselves beyond the limits at which adults are found, but the presence of adults may be taken as defining the limits within which the species can establish itself. In the case of Port Erin, in June, 1933, for example, no adults were found below a level of $-6^{\prime} 2^{\prime \prime}$, although there were spat of that year's brood a foot below that level.

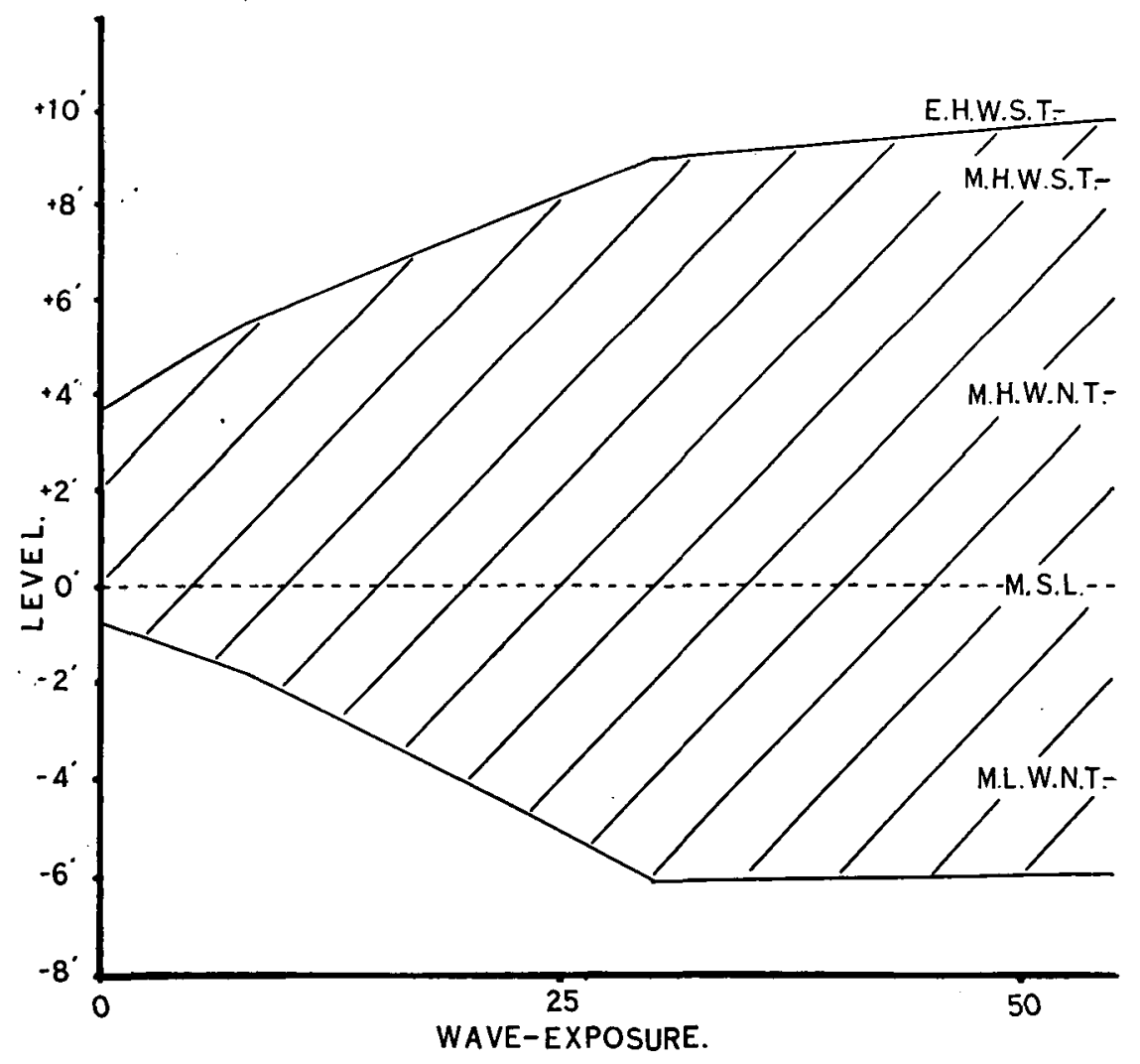

Fig. 1.-The variation in the upper and lower limits of distribution of B. balanoides with varying degree of wave-exposure. H.W.=High water; L.W.=Low water ; M.S.L.= Mean sea level; $M=$ mean $; \mathbf{E}=$ equinoctial; S.T.=Spring tide; N.T.=Neap tide. 
The upper limit at the very sheltered locality at Port St. Mary inner pier is almost exactly at high water of mean neap tides, and Fischer-Piette (1929) states that this upper limit is adhered to all along the Channel coasts. With increasing exposure to wave-action, the upper limit rises, until outside Bradda it is almost at high water of extreme spring tides, but it must be remembered that these levels are absolute, and do not take into account the extent of the splash-zone (Orton, 1929, p. 279), which would probably be sufficient alone to account for this added six feet. However, in calm weather, these barnacles must have to exist for days at a time without being touched by the water.

The lower limit of distribution drops similarly with increasing waveexposure, from just below mean sea level at Port St. Mary inner pier to half-way between mean low water neaps and mean low water springs at Port Erin. The fact that there is no further drop outside Bradda suggests. that this is the lowest limit at which they can establish themselves. The abnormally good spatfall of 1933 populated the rocks at Port Erin down to $-7^{\prime} 8^{\prime \prime}$, but no mature animals were found to have survived below $-6^{\prime} 2^{\prime \prime}$.

The connexion between the upper limit and high water of neap tides is obvious, suggesting that, except for short periods, this species require to be reached by the water every day. And it may be noted that those barnacles which live at the extreme top limit are few in number and thick shelled. The reason for the lower limit is, however, not clear. If we assume that for an animal which requires the intertidal conditions of contact with both air and water each day the splash zone will not only raise the upper limit of high water, but also drop the level of low water, since the wash of the waves will carry air to a level below actual low water mark, then the observed drop in the lower limit for Balanus at increasing wave-exposures may be to some extent accounted for. This species. definitely requires these intertidal conditions since it is not normally found below the level of low water, and since, except in the type of locality found outside Bradda Head the species thrives best as an adult at the top of its distribution. At any rate some powerful limiting factor must be operative since outside Bradda the lower limit is so sharply defined, and yet immediately above it is the zone of earliest maturation, and of the most rapid growth rate which has been found in the neighbourhood. Further it seems probable that a different factor is responsible for raising the lower limit in more sheltered localities, where low water conditions are definitely disadvantageous to all but the youngest barnacles (see p. 288). 


\section{Relation of Denstty of Population to Wave-Exposure.}

That wave-exposure situations are advantageous to the growth of this species has already been shown (Fischer-Piette, 1929). Numbers of individuals are an unsuitable measure of quantity in comparing different barnacle communities, since in tightly packed areas the largest numbers will be found where the barnacles are smallest, and the largest numbers of all will of course be found in recently denuded rocks which have been heavily recolonised by spat. A better figure to use is the weight of tissue per unit area. Taking all ages of barnacles together, the maximum weights found at any level were, in order of ascending wave-exposure, 1.4, 8, 24 and $178 \mathrm{mgm}$. per sq. metre.

Fischer-Piette has further stated (1929) that the advantageous effect of wave-action on the growth of barnacles may be reproduced by a current of water. This was confirmed by observations in the Clyde and at Plymouth, and also in material collected for me at Lough Ine, in Ireland, by Dr. M. W. Parke. This latter material consisted of samples taken from approximately the same tidal level at three localities. The first of these was inside the lough where there was very little wave-action and practically no current. The second was in the rapids which connect the lough with the open sea, and in which there is little true wave-action, but a very strong flow of water. The third was in the open sea on the very wavebeaten coast outside the lough. The barnacles from inside the lough were small and those from the open sea much larger, while those from the current-swept region of the rapids were definitely of the large outside type. A further effect of currents is discussed later (see p. 295).

\section{Modifying Influence of Wave-Exposure on the Effect of Level} on Growth Rate, Body Weight, Density of Population, etc.

The simplest condition with regard to the two factors of level and waveexposure is found in the newly settled spat. The samples taken in JuneJuly clearly show that the largest first-year barnacles, and consequently those which have grown most rapidly (because settlement occurs simultaneously at all levels), are those which are living at low water, and further that growth has been progressively less towards high water (Fig. 2). This generalisation holds good for all degrees of wave-exposure, but the general rate of growth is greatest in the most exposed situations. Among the older animals, however, conditions are more complicated (Fig. 3). In the very exposed situations outside Bradda the same condition of greatest growth rate at low water holds good for the second- and third-year barnacles also; but at all the more sheltered stations the optimum level for growth moves steadily up the shore with advancing 
age, so that the oldest barnacles are growing fastest at the top of their distribution. This is also shown in Moore (1934), Figure 3, where the midzone barnacles B.2, were considerably larger in their first year than the

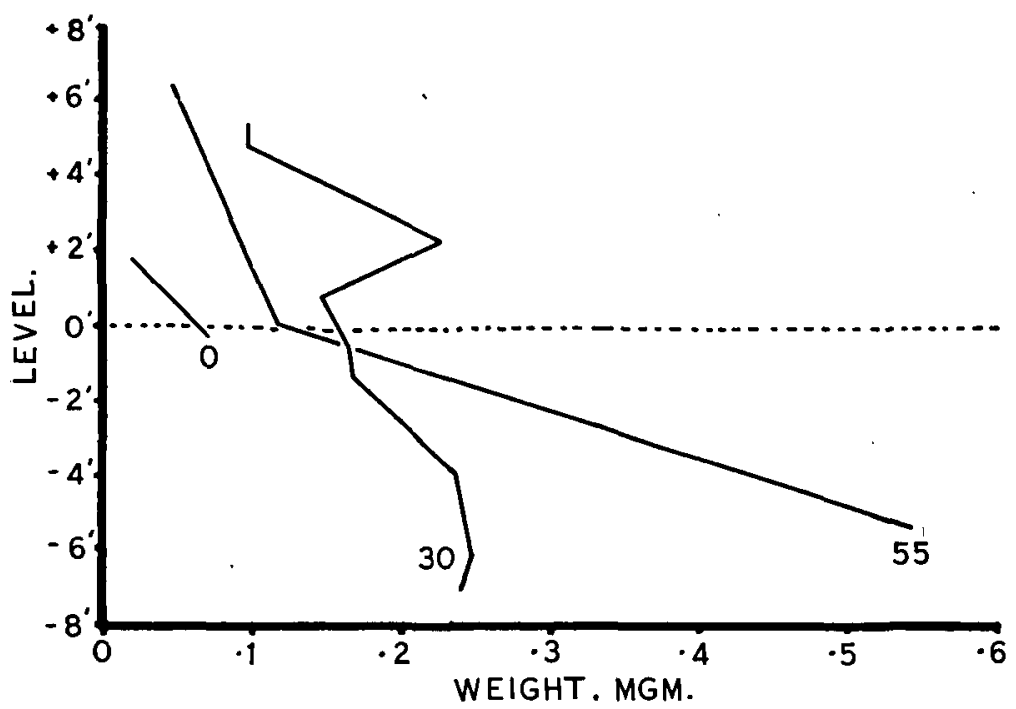

Fia. 2.-Variation in the mean size (tissue weight) of the population with tidal level at different degrees of wave-exposure (indicated by figures alongside curves). Firstyear individuals only.

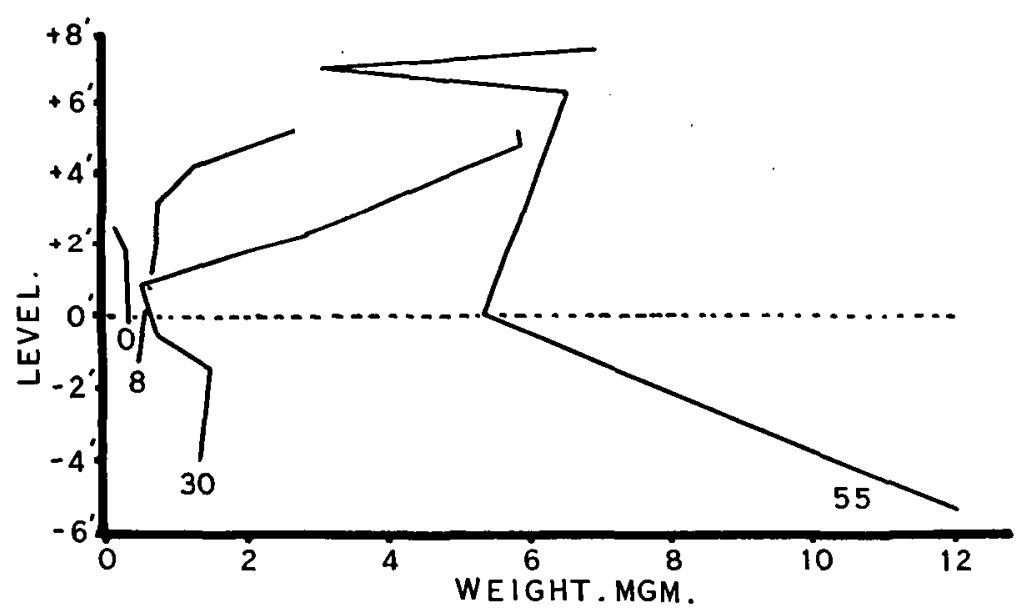

Fra. 3.-Variation in the mean size (tissue weight) of the population with tidal level at different degrees of wave-exposure (indicate by figures alongside curves). Individuals of two years old and over.

corresponding top-zone ones on B.3, but were slightly smaller in their second and subsequent years. Figure 4 of the present paper shows typical areas of rock at Bradda and Port St. Mary, and illustrates the population 

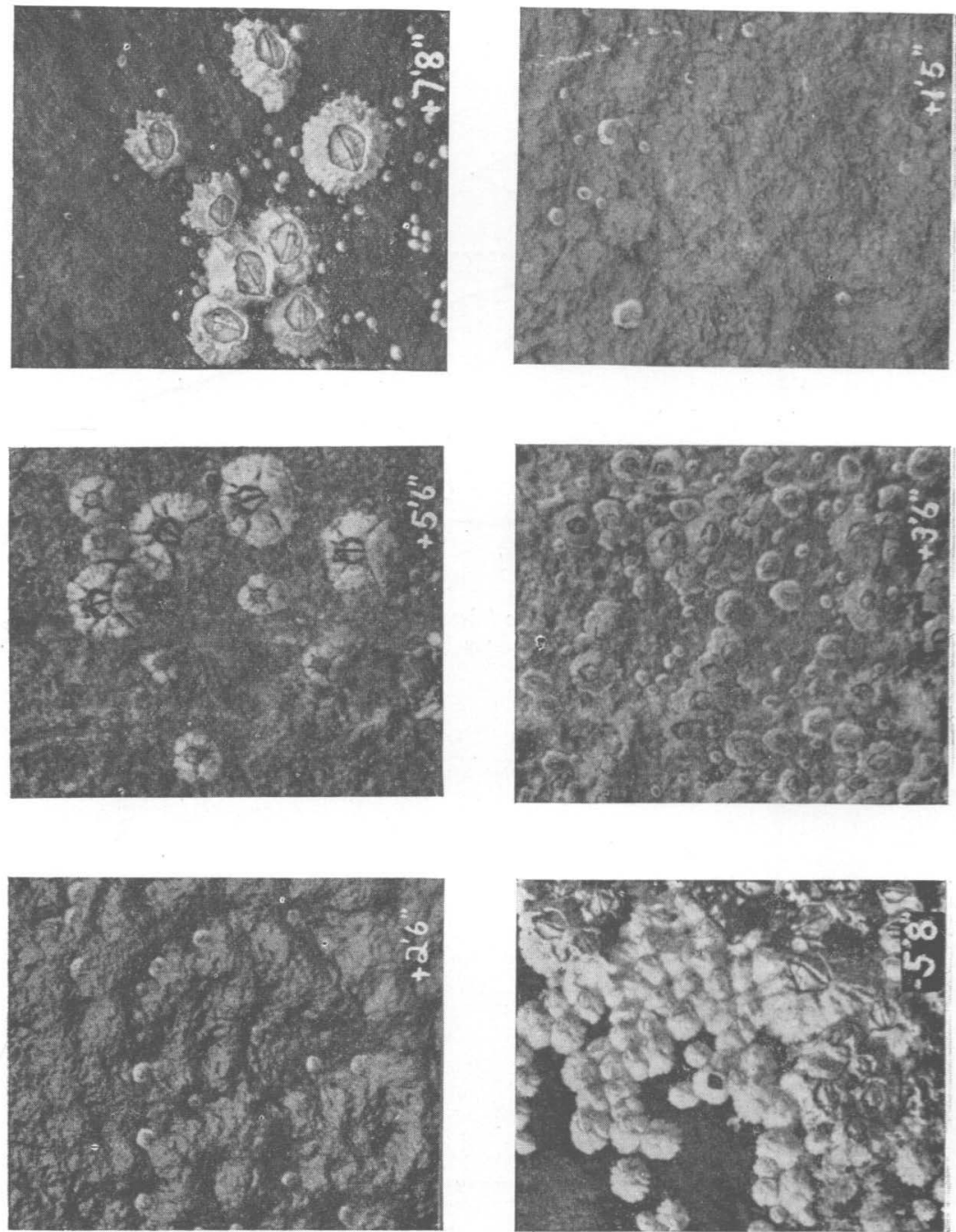

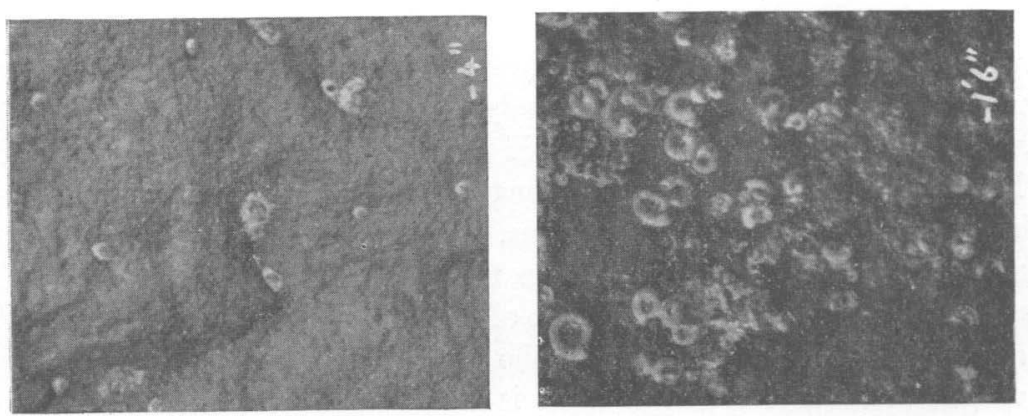

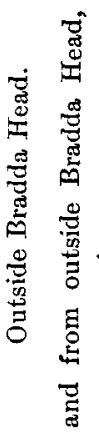
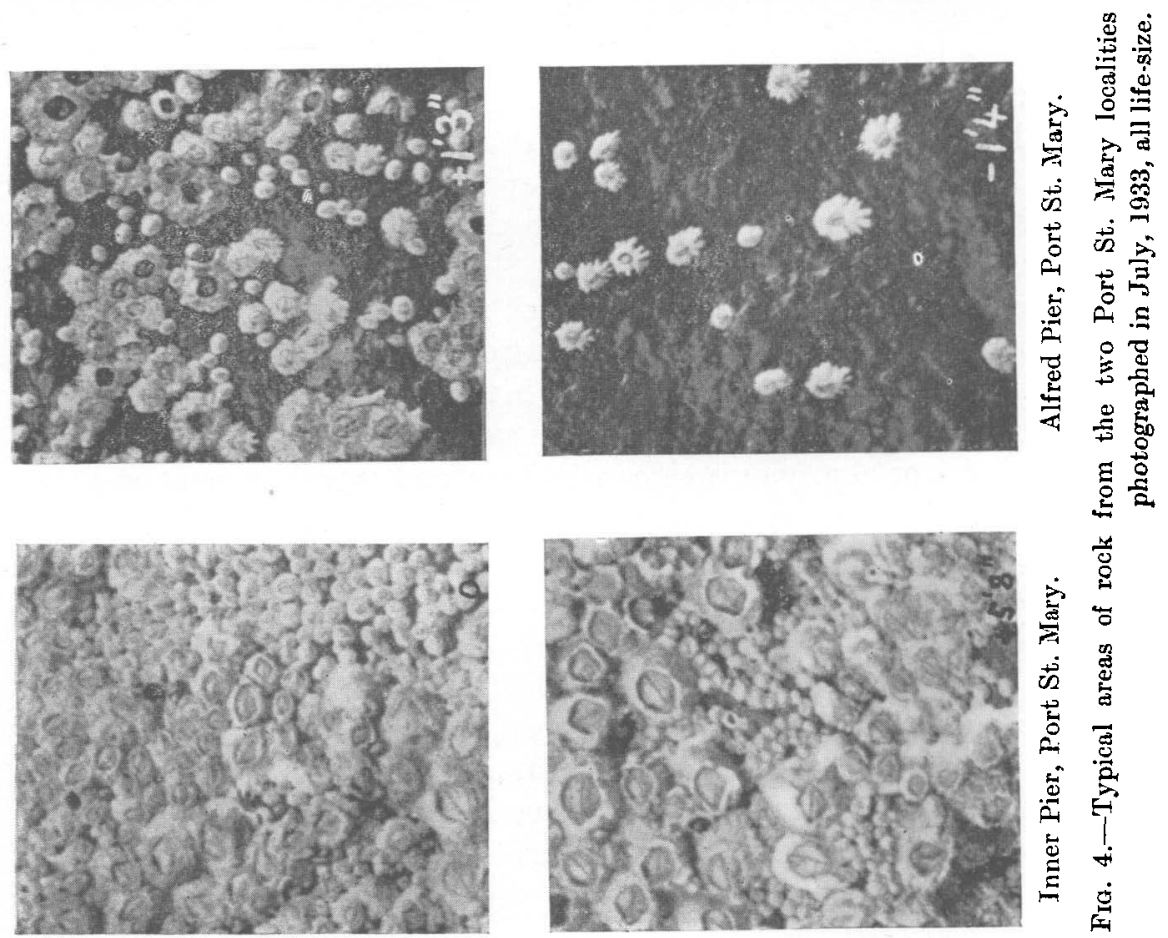

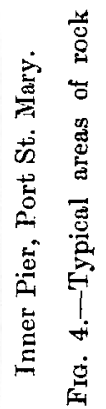


density, and the size attained by first-year and older barnacles in relation to tidal level and wave-exposure. Fischer-Piette (1932) also has recorded the more rapid growth of the newly settled spat at low water and in exposed situations, but he does not give data on the comparative growth of the older barnacles.

The advantage of the low water conditions for the young barnacles is understandable, since they are comparatively thin-shelled and little able to withstand dessication. All ages also will be able to feed for a longer period at low water, and will be able to filter the greatest amount of water where this water is being moved by waves. But it would appear that either there is a harmful factor present in the water in more sheltered situations which tends to retard the growth of the older barnacles, but not of the spat, and perhaps thereby raises the lowest limit at which they can survive (see p. 283), or else that there is a beneficial factor in a condition of exposure to the air. Such a factor would be counterbalanced in the young barnacles by their difficulty in withstanding dessication. It is true that they are less liable to the attacks of enemies such as Purpura at higher levels, but this would affect their death rate and not their rate of growth. And it must be remembered that the barnacle is a planktonfeeding animal which is dependent on the period when it is covered by the water for obtaining its food.

In those localities where the supply of food is more than usually abundant as outside Bradda, where an extra large quantity of water is brought within reach of the barnacle, and in the quiet waters of the River Tamar at Plymouth, where the water is very rich in suspended food matter, this factor clearly outweighs all others, and growth is greatest at low water. But where such strongly beneficial low water conditions are not.present a second factor comes into play, and of the two possibilities suggested above, that of the harmful factor in the water seems to be the more likely.

It has already been shown (Moore, 1935, 1) that the ratio of tissue weight to shell volume varies with season, age and tidal level. The results of the present survey bear out, so far as they go, those obtained at Port Erin that the relative weight of tissue is in general greatest at low water, and is greater in mature than in immature individuals.

The Effect of Level on the Maturation of the Gonads, and the Modifying Influence of Wave-Exposure on This.

In Moore (1935) it was shown that, at Port Erin, maturation of the gonads occurs in the first year in barnacles living below half-tide mark, but not until the second year in animals from above this level. In February, 1934, a survey was made of the conditions of the gonads at the four Isle 
of Man localities at a time when all spawning barnacles contained welldeveloped larvæ in the mantle cavity.

In the upper levels at Port Erin a non-spawning type of barnacle was found which was described as senile (Moore, 1935, p. 270). At the two Port St. Mary localities specimens were found of another non-spawning type in which gonads had failed to develop at any age, as distinct from the senile barnacles which had ceased to develop genital products after a

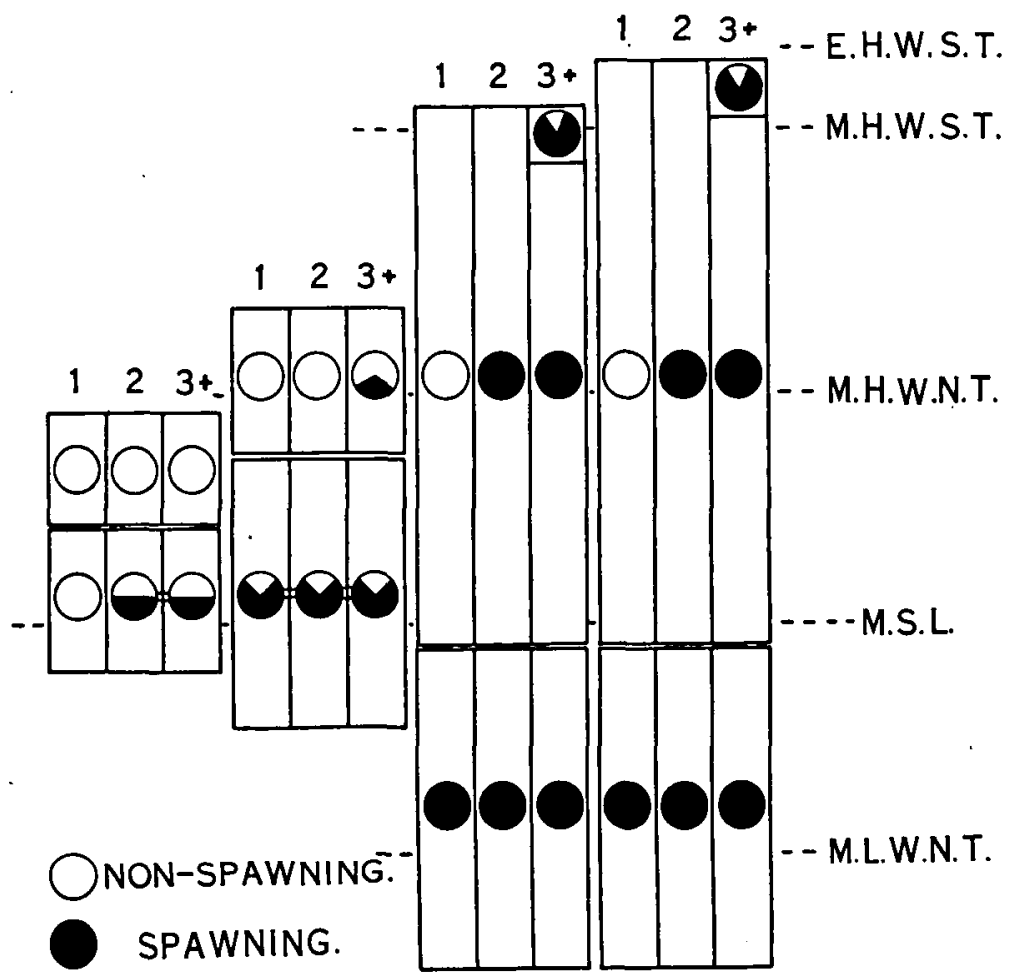

Fig. 5.-Diagram of the condition of maturity of the gonads in relation to age and tidal level (age in years is indicated by the figures at the top), at Port St. Mary inner pier (left), Port St. Mary Alfred pier, Port Erin and outside Bradda Head (right), in February, 1934.

period of normal spawning. In some zones it is normal for there to be one vegetative year before the gonads mature, and this condition of sterility appears to be an extension of this vegetative period due to adverse conditions. Fischer-Piette (1934) records that at the Scilly Isles, at the extreme western limit of their range in Great Britain, the Balanus were not producing any larvæ. The sterile individuals at Port St. Mary could be readily distinguished from the senile ones by the condition of the basal membrane. This was thin and dark in the sterile barnacles as it is in young 
immature individuals, while in the senile ones it was yellow and swollen with degenerating relict ova.

At Port Erin and Bradda conditions were very similar (Fig. 5). Below about half-tide level all the barnacles matured in their first year, and liberated larvæ when a year old (counted from the time when they were spawned). Above this level maturation did not occur until a year later, but occurred then in all individuals. In the third year a proportion of senile individuals began to appear, though no definite figure can be given to their frequency, since the condition is progressive.

At the Alfred Pier, Port St. Mary, in the lower zone, about $75 \%$ of the barnacles were mature, the rest apparently not maturing. Unfortunately it was not possible to separate the year groups here with certainty, but it appeared probable that there were present both mature and immature barnacles of all ages. In the upper levels, where the year groups were more readily distinguishable, no mature barnacles were found in the first- or second-year groups, and in the third-year group only about $30 \%$ were mature.

Finally, in the very sheltered situation of the inner pier, Port St. Mary, no mature individuals at all were found in the upper levels, and in the lower zone only about $50 \%$ of the two-year-old and older barnacles were mature. No mature first-year barnacles were found here.

The effect of increased exposure to wave-action is therefore to accelerate the onset of sexual maturity, and this always occurs earlier at low levels on the shore than it does higher up. A full series may be obtained of barnacles maturing in their first, second or third years or not at all.

\section{The Effect of Temperature, Salinity, Oxygen Concentration, $\mathrm{PH}$, and Sediment.}

Observations on the environmental conditions are unfortunately few. A barnacle living between tide marks is exposed to two entirely different types of conditions according to whether it is immersed or exposed. When exposed to the air, the barnacle's shell is closed, and the barnacle is extremely resistant to adverse outside conditions. Also, if immersed in water which is in any way harmful, the shell can be closed and the animal protected for a considerable period. It must be able to avoid desiccation for some time when left by the tide, probably on some occasions for as much as a week in extreme instances such as outside Bradda. Cole (1932) records an experiment in which a group of $B$. tintinabulum were removed from the sea which was at a temperature of $11^{\circ}$ to $16^{\circ} \mathrm{C}$., and were left in the sun at a temperature of well over $50^{\circ} \mathrm{C}$. for twelve successive days. At the end of this period they were returned to the water and re-established normal cirral movement within six hours. We ourselves have recorded a 
temperature of $36 \cdot 3^{\circ} \mathrm{C}$. inside the mantle cavity of Chthamalus stellatus at Plymouth, while the barnacles were still attached in their normal position on the rocks, and this was not by any means on the hottest day in the summer.*

On the other hand Cole (1932) says, " . . . Contrasted to the marked resistance when the valves are closed is the extreme sensitivity of the open barnacle to environmental stimuli. Intense stimuli cause immediate withdrawal of the cirri and closure of the valves. Mild stimuli cause irregularity of the cirral movements, ... Included in such effective stimuli are not only a great variety of chemical compounds, but decrease in illumination (shading reflex), changes in temperature, mechanical vibrations, rate of water flow and contact stimuli."

In Cole (1929) he gives the temperature at which the maximum rate of cirral movement is obtained as $21 \cdot 0^{\circ} \mathrm{C}$. Below $2^{\circ}$ the movement was irregular, as it was between $21^{\circ}$ and $27^{\circ}$, where also it was often accompanied by closure of the valves, and above $27^{\circ}$ they invariably closed.

Runnström (1925) gives the sea surface temperatures at Herdla as $14-15^{\circ} \mathrm{C}$. in summer and about $4^{\circ} \mathrm{C}$. in winter. He points out that in th first vegetative year there are two periods of shell growth corresponding to the two times of year when the sea is at its mean temperature. In the barnacles at Port Erin there is some indication of this same double growing period of the shell associated with the time of mean temperature, although it is not always traceable. There is also (Moore, 1935, p. 264) decrease in the rate of production of tissues during the period of highest temperature in some barnacles, although this seems to be conditional on the state of sexual maturity of the animal.

An examination of the data given by Johnstone, Scott and Chadwick (1924) for the plankton of Port Erin Bay shows that while there is a considerable variation in the numbers of nauplii and of cypris taken in different years, yet there is no apparent connexion between this variation and the sea temperature. Thus 1912, 1913 and 1917 were years in which very high numbers of nauplii were taken, and the sea temperatures during the February-April period of these years were respectively $4 \cdot 2 \%$ and $5 \cdot 6 \%$ above the mean and $24.0 \%$ below it. Further, the years in which there were large numbers of cypris larvæ were not necessarily those in which there had been large numbers of nauplii. In fact it seems likely that the abundance of larvæ near the shore is more dependent on the degree of their dispersal by currents.

Fischer-Piette (1929) gives the limiting values found by him for some of the factors at la Rance. Prennant and Teissier (1929) state that this

* I am indebted to Dr. L. E. Bayliss for assistance in recording these temperatures,. which were measured with a small thermocouple inserted into the mantle cavity of the barnacle.

NEW SERIES,-VOL. $\mathrm{xx}$. No. 2. AUGUST, 1935. 
species is unable to withstand low salinities, but at la Rance it was found in water with a salinity as low as $0.45 \%$. The range of variation of oxygen and $\mathrm{pH}$ which they could withstand was considerable. The oxygen concentrations of the waters in which they were found to be living ranged from $26 \cdot 0$ to $5 \cdot 8 \mathrm{mgm}$. per litre, and the $\mathrm{pH}$ from $9 \cdot 3$ to $7 \cdot 5$. E. Krepps also has published several papers on the relation of the oxygen consumption of barnacles to salinity, temperature, etc.

Barnacles are strongly favoured by water bearing a large amount of suspended matter on which they can feed, as in the case of the estuary of the River Tamar, but this may be counterbalanced by pollution of the water resulting in smaller size of the barnacles, as is found in the River Mersey.

\section{The Effect of Crowding.}

Barnacle larvæ will frequently settle on all the available rock surface, and so close that when metamorphosed they are touching their neighbours

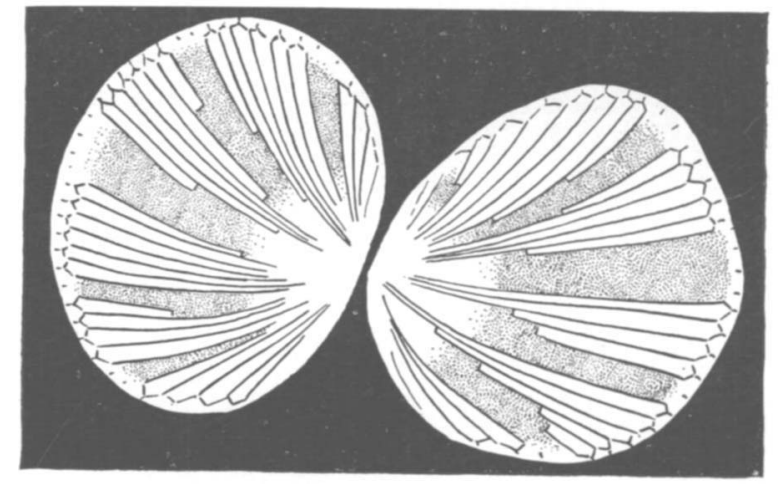

Fia. 6.-Diagram of the basal plates of two specimens of Balanus improvisus which settled in contact at one point, but free elsewhere. The tracks of the radial canals show that growth has been unilateral. $\times 10$.

on all sides. Such overcrowding must result in a heavy mortality, since there is not room for a tenth as many adults, but how the selection takes place is not known. In fairly still water it is probable that the presence of a large number of barnacles will seriously deplete the stock of food in the water to their mutual detriment.

If two barnacles settle so that they are too close together on one side, but are free from obstruction in other directions, they are able to move their bases sideways as they grow, so that, while remaining touching at one point, their centres move apart. The tracks of the radial canals in the basal plates of the $B$. improvisus shown in Figure 6 give evidence of such a shift. If the growing barnacle is crowded on all sides, its only opportunity for growth is upwards, and the result may be a barnacle 
with a ratio of height to length which is three or four times the normal (see Briemen, 1934, p. 248). As such barnacles are supported on all sides by their neighbours, their firmness of attachment to the rock is not affected.

A second effect, and one which is hard to measure is the decreased rate of growth in crowded communities. A fortunate opportunity for observation was given by spat which settled on the B.5 patch in 1932 . Some of of these settled singly and uncrowded on the open rock surface, while series of them settled in a V-shaped groove cut in the rock to mark the patch (Fig. 7). These settled so close together that they were soon overcrowded, as is shown in the photograph taken in March, 1933, in which it will be seen

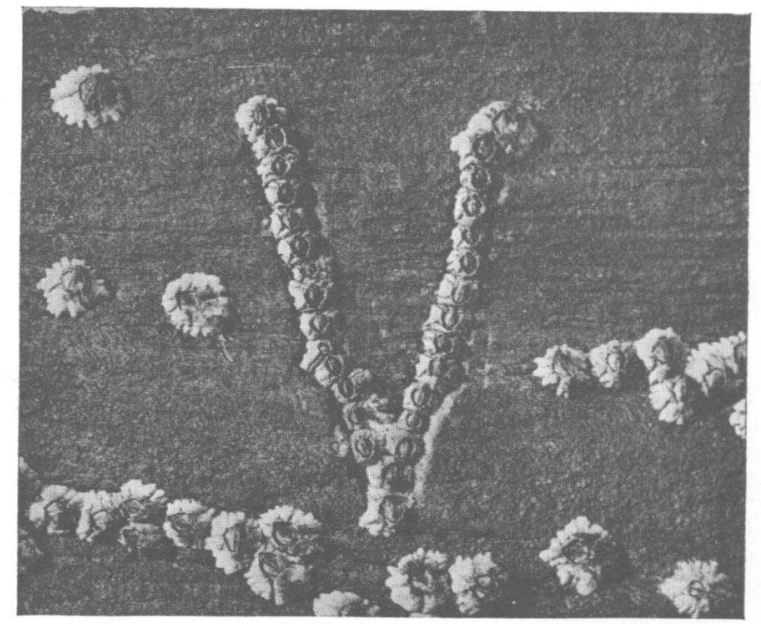

Fra. 7.-Barnacles, all the same age, showing greater growth in isolated specimens than in the crowded ones in the groove. Photograph taken in March, 1933 ; al] barnacles settled the previous spring. $\times 1$.

that the isolated barnacles, and those at the ends of the grooves are considerably bigger than those packed together along the grooves. In February, 1934, when these barnacles were nearly two years old, they were removed from the rock and measured, with the following results. The isolated individuals had a mean volume of $84.7 \mathrm{~mm}^{3}$., the one remaining living individual from the end of a row was almost as large, with a volume of $75.0 \mathrm{~mm}^{3}$., while the barnacles from the crowded parts of the grooves averaged only $13.3 \mathrm{~mm}^{3}$. The crowded barnacles had not grown to an unusual extent in the unrestricted lateral direction, less so in fact than is frequently seen, so that their deficiency in size cannot be put down to mere physical cramping. It seems more probable that the barnacles, whose apertures were all in alignment along the groove, were filtering the same body of water, at least in still weather, and were thus failing to 
obtain as much food as the isolated barnacles growing near by. This seems to be a likely factor in retarding the growth of barnacles living in crowded clusters.

In this connexion, there is a form of $B$. balanoides which calls for note, namely var. elongatus Gould (Fig. 8). I have received specimens of it from the River Mersey by the courtesy of Prof. J. H. Orton, and have also collected them at Meols in Cheshire. Starting from a narrow base, these barnacles widen towards the apex, until they are frequently ten times as tall as they are wide at the base. It is not certain whether this form is

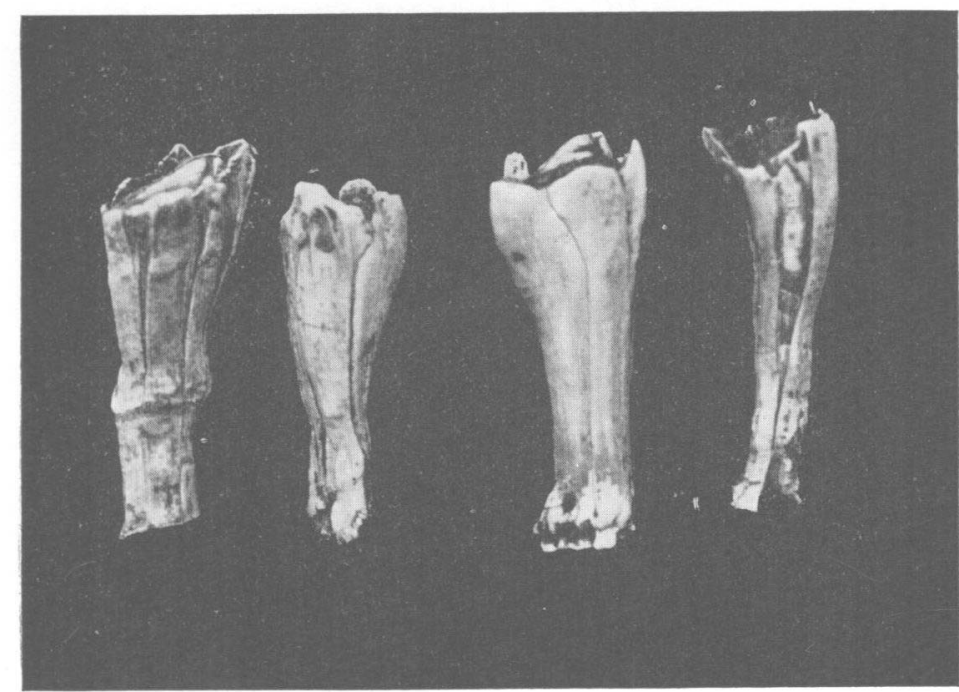

Fra. 8.-B. balanoides var. elongatus Gould. from the River Mersey. $\times$ I.5.

not due in some cases to their having commenced life in a very crowded community, but this is certainly not always the cause since many of them showed no signs of having been attached at the sides to other barnacles. In addition most of those found growing at Meols were isolated. Also many of the latter were colonised round the apex by a younger brood, and sometimes these in turn by a third as may be found in Balanus hameri (Moore, 1934, 2). Since there was plenty of uncolonised surface for attachment alongside it would appear that this was in some way undesirable for attachment, and that the barnacle grew so as to carry their orifices as far away from it as possible. Those taken in the Mersey were growing on Liverpool landing stage in a strong current (maximum 5-7 knots), in very muddy and polluted water. The salinity varied from 23 to $28 \%$ in summer and from 21 to $27 \%$ in winter. The $\mathrm{pH}$ is normal.*

* Figures kindly supplied by Mr. J. H. Fraser. 
The conditions at Meols were more normal, although the water was far from clear, and the piles on which the barnacles were growing were above a bottom of mud.

\section{Settlement of the Larve.}

Vischer (1928) described how the cypris larvæ of Balanus move about. the surface on which they settle, apparently testing it, until they find a suitable place to metamorphose. He states (p. 330) that this process may last for over an hour, and that during it the larvæ may travel as. far as twelve millimetres. It has also been shown (Vischer, 1928 ; Vischer and Luce, 1928; and Neu, 1933) that the settling cypris is negatively heliotropic, and that for lights of equal intensity it is most responsive to green. Finally, if there is a continuous flow of water over the surface of attachment, the barnacle will tend to attach and metamorphose with its long axis along the direction of flow of the current (see p. 296).

On the shore it is frequently seen that the barnacles have settled closely along cracks and grooves in the rocks, like those shown in Figure 7. The barnacles in such grooves are frequently orientated with their long axes along the groove. On the open rock surface, on the other hand, they are apparently orientated haphazard. The much higher degree of concentration of barnacles in the grooves than on the neighbouring smooth surface (see Fig. 7), shows that the cypris must have explored the surface and chosen by preference the shelter of the groove. Possibly they may do this on account of the slightly lower level of illumination there, or possibly for the actual shelter from dislodgement, but this is improbable since Fischer-Piette (1932) has shown that more larvæ settle on exposed rocks than in quiet waters. He also states that the numbers of larvæ settling on the shore are greatest at low water, but that the actual number is not simply related to the number of hours during which that level is covered by the sea. The effect is not therefore due to larvæ settling at a uniform rate for a period of time which is dependent on the period of immersion of the particular level, but is modified by some controlling factor. 'In the Isle of Man, where a greater number of levels were compared, it was found that the newly settled barnacles were distributed in this way, with the greatest numbers near low water, but that the level of maximum spat settlement was at a varying height above their lower limit, and in some cases as high as half-tide mark.

\section{The EFfect of Current.}

The effect of currents in producing large barnacles of the type associated with wave-exposed localities has already been described (p. 284). The reason is perhaps to be found in the fact that in moving water more food 
will be brought within reach of the animal in a given time than in still water.

A second effect is found in the orientation of barnacles growing in a current of constant direction, but this is rarely found on the open shore where the direction of flow of the water is continually changing under the action of waves. It has been shown (Moore, 1933) that Balanus improvisus growing in a continuous current, or in an intermittent current of constant direction, tend to settle with their long axes along the current. Immediately after metamorphosis the barnacle commences to rotate, as is shown by the record kept by the radial canals in the base of the shell. These canals follow the successive positions of the wall plates of the shell, and show that the barnacle has gradually rotated through about $90^{\circ}$ (Fig. 9).

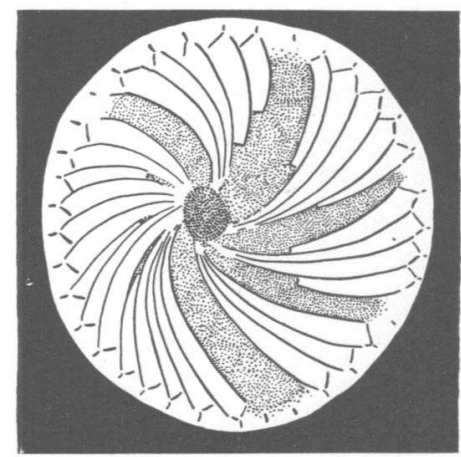

Frg. 9.-Diagram of the basal plate of a specimen of Balanus improvisus growing in a current of water. The tracks of the radial canals indicate rotation through about $90^{\circ}$.

After this, in older specimens, rotation has stopped completely and growth has been simply radial.

Since $B$. balanoides has a membranous base it does not retain any such individual record, but the same process may be traced by estimating the mean deviation from the current of successive sizes of barnacles in a suit:able locality. Such a situation was found on the inner side of the wooden piles of Fairlie Pier in the Clyde. These were to a large extent sheltered from wave action, and at the same time were subject to a steady tidal . current of about two knots. The locality was examined in June, 1934, when the angular deviation from the direction of the current was measured for 198 young barnacles of $1-4 \mathrm{~mm}$. long and of the 1934 brood, and for 204 individuals, $16-23 \mathrm{~mm}$. long and several years old. The results are shown in Figure 10, and indicate clearly the change from the alignment of most of the spat along the current to the adult condition with most of the barnacles lying across the current. Actually the observed results could have been produced by a selective action in which those few barnacles which had settled across the current survived more readily than 
those which had settled along it, but in view of the positive evidence from $B$. improvisus it seems more likely that they rotated.

Observation of a barnacle when feeding suggests a possible reason for this rotation. The cirri together form a cup-shaped net, and in normal feeding movements in still or very slightly moving water this net is alternately extended and retracted along the same plane in which it normally lies in the shell. Occasionally, however, if the temperature is

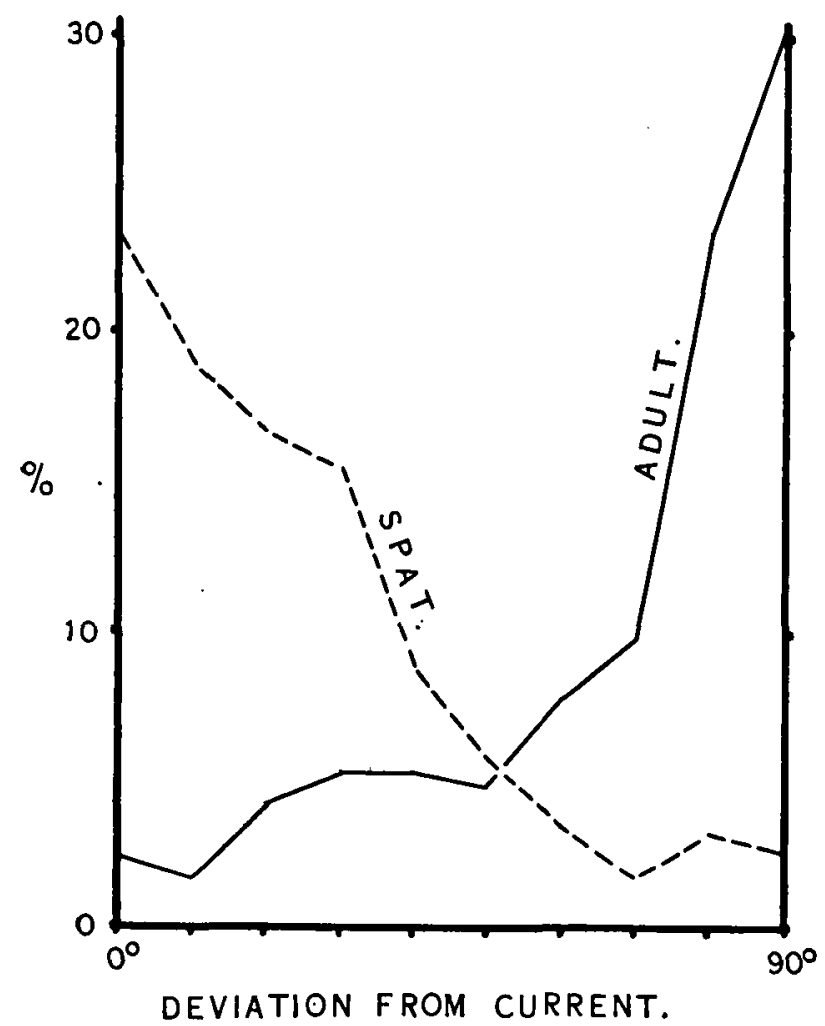

FIa. 10.-Distribution diagram of $B$. balanoides on Fairlie Pier, in terms of angular deviation from the direction of flow of the current: young and adults.

not too low, this movement may be varied, and the cirri may be held extended for a second or more and sometimes twisted to one side. If a current of water is passed over the barnacle, certain results tend to be produced, although not invariably seen. If the barnacle is lying so that the current impinges on the back of its net of cirri, it frequently retracts its cirri and closes its shell, obviously finding difficulty in capturing any food particles in its net. If, however, the barnacle is facing in the opposite directions, so that the water impinges into its cirral net the barnacle tends to stay extended for a longer period, especially if the current is strong, 
and retraction then becomes dependent on some particle touching the cirri. Clearly this method of feeding, while equally effective, will require less expenditure of energy on the part of the barnacle.

If the barnacle is lying at right angles to the direction of the impinging current, it frequently extends its cirri, and then turns them at right angles so that the whole net faces up the current, in which position it holds them until contact with a food particle stimulates contraction. Clearly then, the best position for a barnacle to take up when feeding in a current of water is that in which its cirral net is facing up the current, and when not naturally facing in this direction it can twist its body through as much as $90^{\circ}$ so as to face in the required direction. Apparently, however, it is unable to twist through more than about a right angle. Where, therefore, a barnacle is situated in a strong tidal current which reverses its direction of flow periodically, orientation along the current would allow the barnacle to feed for only half the period during which the current was sufficiently strong to effect it, whereas feeding could be continuous if the shell were orientated across the current and the body always twisted in the required direction. And since the cypris larva normally settles with its long axis. along the current, a twist through one right angle will achieve the desired result. In the case of the $B$. improvisus mentioned above, some of the barnacles were growing in a stream of water which was always in the same direction, and never reversed. The bases of the barnacles showed, however, that they had rotated through $90^{\circ}$ only and then stopped. After metamorphosis of a cypris larva in a current of water, the newly-formed barnacle would be orientated with its cirri facing down the current of water in a position most disadvantageous for capturing food, and rotation would clearly be desirable. Perhaps when the shell has been rotated far enough for the cirri to be twisted into the direction of the current, the stimulus to rotate the shell ceases.

\section{Relation to Other Dominant Organisms.}

In the Irish Sea and the North Sea the dominant intertidal barnacle is $B$. balanoides. Along the western end of the English Channel coast its place is largely taken by Chthamalus stellatus, and Fischer-Piette (1928 and 1934) has given an account of their distribution in this region. At the western end, Roscoff on the French side and the Scilly Isles on the English side, Chthamalus is common at all levels, and $B$. balanoides either absent. or restricted to the lowest levels. Progressively eastwards Balanus becomes more common and extends upwards to higher levels, while Chthamalus becomes rarer and finally disappears. In sheltered localities, where Chthamalus thrives less well than Balanus, the process of replacement takes place further west than it does on exposed headlands. At the 
western limit of their distribution the Balanus are small and do not produce any larvæ.

At Port Erin, Chthamalus does not normally occur, although it was recorded as abundant in one locality there in 1886 (Marrat, 1886). As it has not been recorded since it seems likely that this was an abnormal year in which larvæ were carried by current to the Manx shores which they infected, but where they did not survive as an established species. The species is present in small numbers in the Clyde Sea Area, and Dr. J. A. Kitching has found it recently at Loch Sween.

At all the localities examined in the Isle of Man, the lower limit of distribution of $B$. balanoides was fairly sharply defined, and below this their place was taken by the polychæte worm, Spirorbis borealis Daudin. As the latter occurs abundantly in small areas uncolonised by Balanus although above the barnacle's lower limit, it would appear that Balanus is dominant and that Spirorbis grows only where the barnacle is not able to.

The presence of large algæ such as Fucus spp., Ascophyllum nodosum, etc., is definitely harmful to the barnacles, and in most places they are not found within touching distance of them ; in the River Tamar at Plymouth, however, where the water is extremely rich in suspended food material, $B$. balanoides has been found thriving and very large under a heavy carpet of Ascophyllum. This suggests that the harmful effect of the algæ is at least in part due to their screening the barnacles from an adequate food supply.

The chief enemy of barnacles is Nucella (=Purpura) lapillus, whose main food they are. This species is found feeding on barnacles practically everywhere, but it does not penetrate so far into brackish water as does B. balanoides (Fischer-Piette, 1931), and in very wave beaten situations the Nucella are unable to feed on the open rock surfaces in rough weather, and are in consequence fewer in numbers. Day $(1880$, p. 204) quotes a statement of McIntosh's that barnacles are eaten by Blennius pholis at St. Andrew's. Elmhirst (1922) also states that in the upper levels the newly settled barnacles are eaten by Littorina saxatilis (=L. rudis). I have not been able to obtain confirmation of this, nor to observe that the Littorina do more than shelter in the already empty shells of dead barnacles, and browse on the algæ infecting the shells of the older ones.

Finally Allison and Cole have recently demonstrated the interesting fact that $B$. balanoides is sensitive to the constitution of the plankton in the water in which it is feeding, remaining closed when peridinians are abundant, but opening and feeding when the plankton is comprised of diatoms and other organisms. 


\section{Estimate of the Total Barnacle Population of the Shore and its Annual Food Output.}

The figures given in the tables at the end of this paper allow a calculation to be made of the total amount of barnacles on a metre-wide strip of shore running vertically from high to low water at each locality. So far as numbers of individuals are concerned, if we omit the first year spat, the amount rises steadily with increasing wave-exposure, but if the spat are

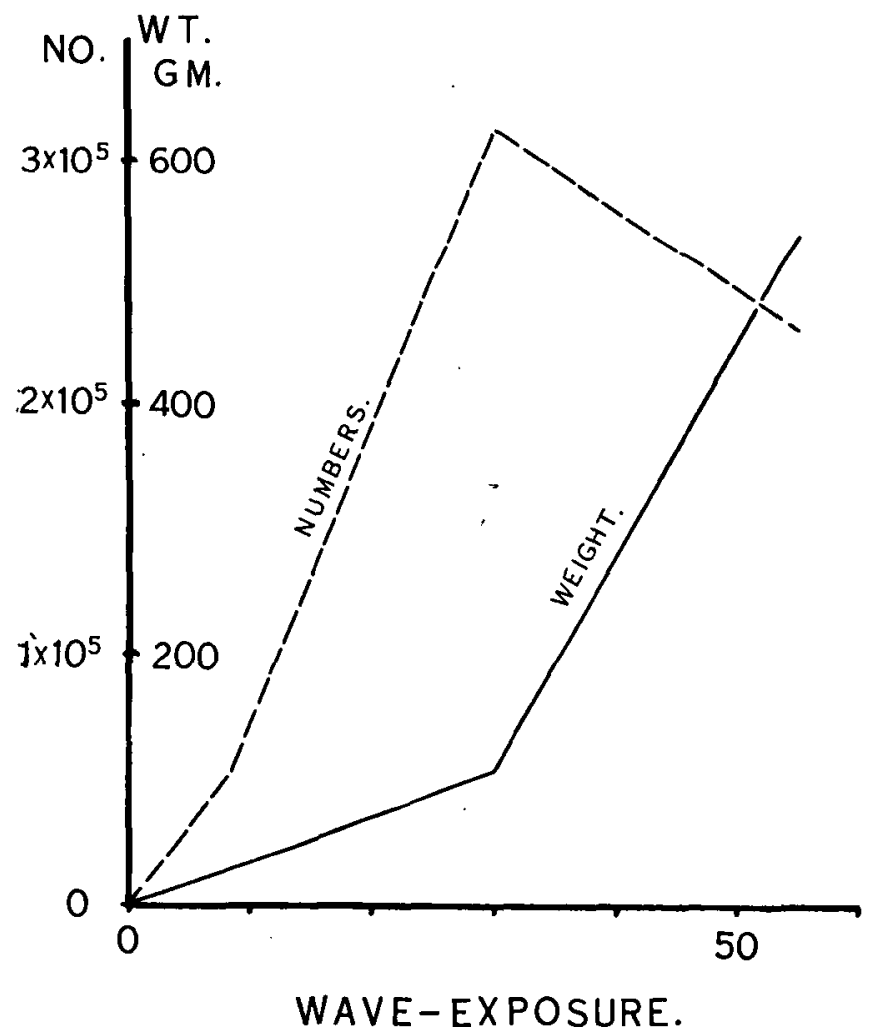

Fia. 11.-The relation between amount of barnacles (numbers and weight of tissue) on a metre-wide vertical strip of shore, and wave-exposure.

included the numbers are greatest at Port Erin (Fig. 11). This is accounted for by the smaller average size at Port Erin and hence the possibility of a greater number per unit area of crowded population. When, however, weights are compared, and these are the most adequate measures of the amount of barnacle present, the values rise steadily with increasing exposure, the values being, in order of increasing exposure, 7, 27, 106 and $542 \mathrm{gm}$. of dried tissue.

These figures apply only to a vertical plane surface of rock, but it is of 
interest to obtain some estimate of the total amount of barnacles on the shore. If we multiply such figures by two for the increased area of a sloping shore, and multiply again by two for the increased area due to irregularities of the surface (a minimum figure in the latter case), we have a very rough approximation of the amounts on normal stretches of shore of the types studied. This gives a value of about two thousand kilogrammes of dried tissue per kilometre of normal shore of the degree of waveexposure found outside Bradda, and about eight hundred kilogrammes for the Port Erin type of shore.

Not all this amount of total available food is liberated into the sea each year, but a figure for the output may be obtained. Runnström states that at Herdla most barnacles die after their first spawning when they are a little over two years old, a possible few only surviving to spawn a second time. At Port Erin the observed mortality of a small number of over four months old was $35 \%$ at B.1, and $21 \%$ at B.2 (Moore, 1933). And at $+4^{\prime} 10^{\prime \prime}$ outside Bradda in July, one-year-old barnacles (excluding that year's spat) formed about half of the population. If we apply Runnström's figures we get the following results. On a metre-wide vertical strip outside Bradda, the 86,000 barnacles in their second or subsequent year would mostly die. Their dry weight is $516 \mathrm{gm}$., so that they would contribute about $400 \mathrm{gm}$. dry weight of tissue to the sea. The addition to this of first-year spat would be relatively small. At Port Erin the first-year spat would yield about $40 \mathrm{gm}$., and the older barnacles about a further $40 \mathrm{gm}$., or $80 \mathrm{gm}$. in all. These figures would be equivalent to a yearly output of about $1600 \mathrm{kgm}$. of tissue per kilometre of normal shore of the Bradda type, and 320 kilogramme for the Port Erin type.

If, however, we take a mortality rate based on the mean of the values for B.1 and B.2, namely 28 per cent per annum, we get an output of $600 \mathrm{kgm}$. per kilometre outside Bradda, and $200 \mathrm{kgm}$. at Port Erin. The former is more affected by the change since its population contains a much larger proportion of older individuals.

In addition to this contribution to the sea in the form of body, most of which passes through the stage of Purpura meat, there is an output of organic matter as excreta, as moulted exoskeleton and as larvæ. Of the first two we know nothing, but we are able to estimate the amount of the larval output. To consider first the Bradda type, we must divide the shore into the part above mid-tide level where the barnacles do not spawn until their second year, and the area below this level where they spawn in their first year. Above mid-tide a vertical metre-wide strip will contain 56,000 barnacles of which about half are mature spawners. The average size of the 28,000 spawners is $90 \cdot 6 \mathrm{~mm}^{3}$., and their larval output at this size will be 4200 larvæ each, or a total of 117 million larvæ. Below midtide level there are 31,000 spawners with an average size of $58.1 \mathrm{~mm}^{3}$., 
and average output of 2500 larvæ, and a total output of 77 million. The output from all levels together would therefore be about two hundred million larvæ per year, or about a million million larvæ per year per normal kilometre of shore.

For the Port Erin type of shore the output may be similarly estimated at about twenty million larvæ from a metre-wide vertical strip, or about a hundred million per normal kilometre of shore.

Taking the weight of a single nauplius as $7.5 \times 10^{-4} \mathrm{mgm}$. (Moore, 1935), we get an output of about $600 \mathrm{kgm}$. dry weight of larvæ per kilometre of the Bradda type of shore per year in addition to the $600-1600 \mathrm{kgm}$. of body tissues. At Port Erin there would be $90 \mathrm{kgm}$. of larvæ in addition to the 200-320 kgm. of body. In a very wave-exposed locality, therefore, the contribution to the sea in the form of larvæ is equal in importance to the contribution in the form of general body tissues, whereas in a more sheltered type of locality the larvæ form a relatively small part of the year's output.

In conclusion I wish to express my indebtedness to the staffs of the Plymouth and Port Erin laboratories, and to Mr. R. Elmhirst at Millport, for assistance and advice in this work, and also to Dr. E. Fischer-Piette, Dr. J. A. Kitching and Prof. J. H. Orton.

\section{SUMMARY.}

1. Vertical traverses down the shore were worked at four localities in the Isle of Man, with varying degrees of wave-exposure, for which factor a coefficient is given.

2. The upper limit of distribution is high water neaps in a sheltered place, and up to high water of extreme spring tides at greater waveexposure. The lower limit similarly drops with increasing exposure.

3. Barnacles are largest and most abundant in a wave-exposed locality. The effect of wave-exposure may be reproduced by a current.

4. In sheltered localities the optimum level for growth, mean size, etc., is at low water for newly settled barnacles, but moves progressively up to high water as they grow older. In a very exposed situation, however, the optimum is always at low water.

5. In an exposed situation the gonads mature in their first year below about half-tide level, and in their second year above this level. With decreased wave-exposure the age of maturation rises, especially at high water until in a very sheltered place few barnacles mature at all. 
6. Limiting values for temperature, salinity, oxygen concentration, $\mathrm{pH}$, etc., are given, so far as they are known.

7. Barnacles which are crowded together grow very much more slowly than do isolated individuals.

8. Barnacles grow more rapidly in a current of water. They also tend to orientate themselves with the current-along it when newly settled, and then, by rotation, across it as adults. This is apparently to facilitate feeding.

9. The interrelation with other littoral species is described.

10. The total barnacle population of the shore is calculated. Outside Bradda it amounted to about a thousand million individuals per normal kilometre of shore with a yearly output of about six hundred $\mathrm{kgm}$. of tissue (dry weight), and their yearly output of about a million million larvæ weighing a further $90 \mathrm{kgm}$.

\section{REFERENCES.}

Allison, J. B., and Cole, W. H. 1935. Behaviour of the barnacle Balanus balanoides, as correlated with the planktonic content of the sea water. Bull. Mount Desert Island Biol. Lab., p. 34.

Briemen, L. van. 1934. Zur Biologie von Balanus improvisus Darwin. Zool. Anz., Heft. 9/10, Bd. 105.

Cole, W. H. 1929. The Relation between Temperature and Pedal Rhythm in Balamus. Journ. Gen. Physiol., Vol. XII, No. 5, pp. 599608.

1932. The Sensitivity of the Cirri and the Variability of their Movements in the Barnacles Balanus tintinabulum and B. balanoides. Journ. Exp. Zool. Philadelphia, Vol. LVIII, No. 1, pp. 143-153.

Darwin, C. 1854. A Monograph of the Sub-Class Cirripedia. The Balanidæ, the Verrucidæ. London, Ray Soc.

DAY, F. 1880. The Fishes of Great Britain and Ireland. Vol. I. Williams and Norgate, London.

Elmhirst, R. E. 1922. Notes on the Breeding and Growth of Marine Animals in the Clyde Sea Area. Scot. Mar. Biol. Assoc. Ann. Rept. for 1922 .

Fischer-Piette, E. 1928. Sur la Distribution géographique de quelques Organismes de Rocher, le long des Côtes de la Manche. Trav. Labor. Saint-Servan, II. 
Fischer-Piette, E. 1929. Recherches de Bionomie et d'Océanographie: littorales de la Rance et le Littoral de la Manche. Ann. Inst. océanogr., N.S., T. V, Fasc. 3.

1931. Sur la Pénétration des diverses Espèces marines sessiles dans: les Estuaires et sa Limitation par l'Eau douce. Ann. Inst. océanogr., N.S., T. V, Fasc. 8.

1932. Répartition des principales Espèces fixées sur les Rochers. battus des Côtes et des Îles de la Manche de Lannion à Fécamp. Ann. Inst. océanogr., N.S., T. XII, Fasc. 4.

1934. Sur la Répartition de la Cirripède Balanus balanoides le Long des Côtes Françaises et Anglaises de la Manche. Assoc. France p. Avance. d. Sci., Chambéry.

Hatton, H., and Fischer-Piette, E. 1932. Observations et Expériences sur le Peuplement des Côtes rocheuses par les Cirripèdes. Bull. Inst. océanogr., No. 592, Monaco.

Johnstone, J., Scott, A., and Chadwick, H. C. 1924. The Marine Plankton. The University Press of Liverpool Ltd.

Marrat, F. P. 1886. Notes on the Cirripedia of the L.M.B.C. District. Fuana of Liverpool Bay, Rept. 1, p. 209, London.

Moore, H. B. 1933. Changes of Orientation of a Barnacle after Metamorphosis. Nature, Vol. 132, p. 969.

1934. The Biology of Balanus balanoides I. Growth. Rate and its Relation to Size, Season and Tidal Level. Journ. Mar. Biol. Assoc., N.S., Vol. XIX, No. 2.

- 1935, a. The Rate of Growth of Balanus hameri (Ascanius). Ibid., Vol. XX, No. 1.

1935, b. The Biology of Balanus balanoides III. The Soft Parts. Ibid.

Neu, W. 1933. Der Einfluss des Farbtons der Unterlage auf die Besiedlung mit Balanus da Costa und Spirorbis Mont. Internat. Revue. des ges. Hydrobiol. u. Hydrographie, Bd. 28, Heft 3/4, Leipzig, pp. 228-246.

Orton, J. H. 1929. Observations on Patella vulgata, Part III, Habitat. and Habits. Journ. Mar. Biol. Assoc., N.S., Vol. XVI, No. 1.

PARKe, M. W., and Moore, H. B. 1935. The Biology of Balanus: balanoides II. Algal Infection of the Shell. Journ. Mar. Biol. Assoc., N.S., Vol. XX, No. 1. 
Prennant, M., and Teissier, G. 1924. Notes éthologiques sur la Faune marine sessile des Environs de Roscoff. Cirripèdes, Bryozoaires, Hydraires. Trav. Stat. Biol. Roscoff., 2.

Runnström, S. 1925. Zur Biologie und Entwicklung von Balanus balanoides (Linné.). Bergens Mus. Aarbok., Naturv. Raekke., Nr. 5.

VISCHer, J. P. 1928. Reactions of the Cyprid Larvæ of Barnacles at the Time of Attachment. Bull. Biol., Vol. LIV, No. 4, pp. 327-335.

Vischer, J. P., and Luce, R. H. 1928. Reactions of the Cyprid Larva of Barnacles to Light with special Reference to the Spectral Colours. Ibid., p. 337-350.

\section{TABLE I.}

\section{Distribution of $B$. balanoides Outside Bradda Head, 8th July, 1933. Exposure Factor 55.}

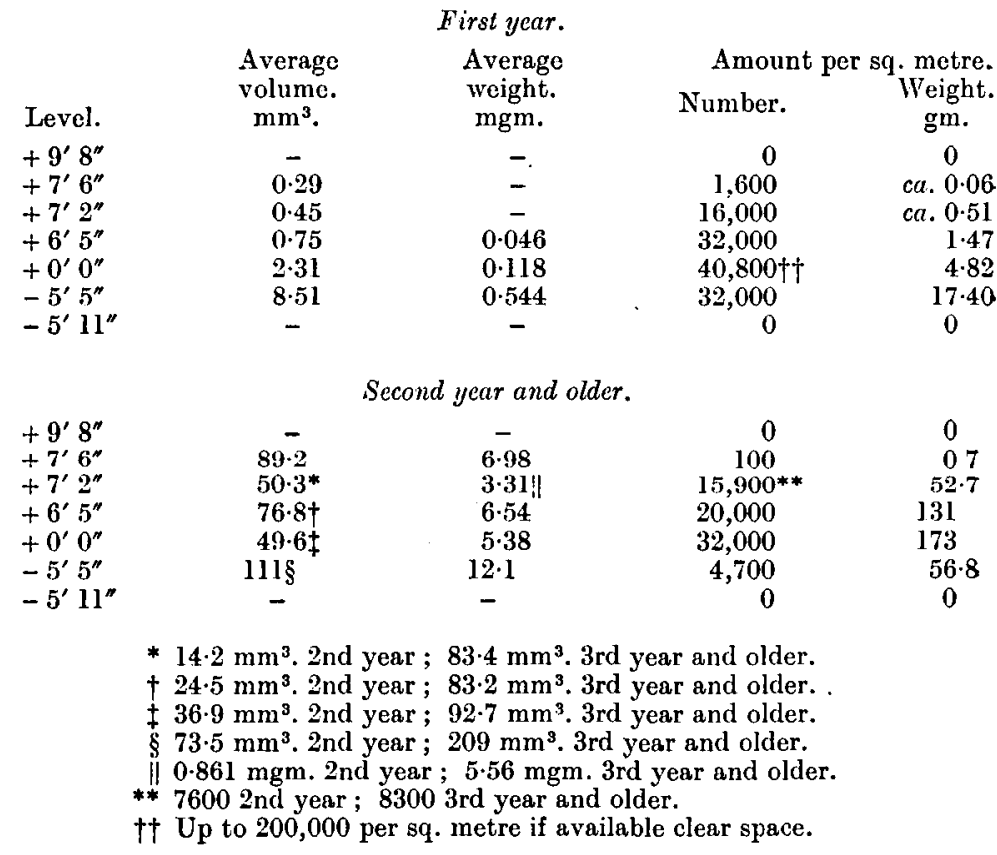




\section{TABLE II.}

Distribution of Balanus balanoides on the Dub Reef, Port Erin. 28th June, 1933. Exposure Factor 30.

\begin{tabular}{|c|c|c|c|c|}
\hline \multirow[b]{3}{*}{ I.evel. } & \multicolumn{2}{|r|}{ First year. } & \\
\hline & Average & Average & \multicolumn{2}{|c|}{ Amount ner sa metre } \\
\hline & $\begin{array}{c}\text { volume. } \\
\mathrm{mm}^{3} \text {. }\end{array}$ & $\begin{array}{l}\text { weight. } \\
\text { mgm. }\end{array}$ & Number. & $\begin{array}{l}\text { Weight. } \\
\text { gm. }\end{array}$ \\
\hline$+9^{\prime} 0^{\prime \prime}$ & - & - & 0 & - \\
\hline$+5^{\prime} 4^{\prime \prime}$ & ca. $1 \cdot 03$ & $c a .0 \cdot 097$ & $c a .200$ & ca. 0.02 \\
\hline$+4^{\prime} 10^{\prime \prime}$ & $1 \cdot 03$ & 0.096 & 8,800 & 0.85 \\
\hline $\begin{array}{l}+2^{\prime} 4^{\prime \prime} \\
\end{array}$ & $2 \cdot 48$ & 0.226 & 84,800 & $19 \cdot 2$ \\
\hline$+0^{\prime} 10^{\prime \prime}$ & $1 \cdot 60$ & $0 \cdot 144$ & 70,000 & $10 \cdot 1$ \\
\hline$-0^{\prime} 8^{\prime \prime}$ & 1.85 & $0 \cdot 163$ & 60,800 & $9 \cdot 92$ \\
\hline$-1^{\prime} 6^{\prime \prime}$ & 1.92 & $0 \cdot 167$ & 110,000 & $18 \cdot 4$ \\
\hline$-4^{\prime} 0^{\prime \prime}$ & $2 \cdot 83$ & $0 \cdot 237$ & 118.000 & 28.0 \\
\hline$-6^{\prime} 2^{\prime \prime}$ & $3 \cdot 00$ & $0 \cdot 246$ & 29,300 & $7 \cdot 21$ \\
\hline$-7^{\prime} 2^{\prime \prime}$ & $3 \cdot 00$ & $0 \cdot 240$ & 3,000 & 0.72 \\
\hline$-7^{\prime} 8^{\prime \prime}$ & - & - & 0 & - \\
\hline \multicolumn{5}{|c|}{ Second year and older. } \\
\hline$+9^{\prime} 0^{\prime \prime}$ & - & - & 0 & - \\
\hline$+5^{\prime} 4^{\prime \prime}$ & $c a .61 .8$ & ca. $5 \cdot 82$ & $c a .30$ & ca. 0.17 \\
\hline$+4^{\prime} 10^{\prime \prime}$ & 61.8 & $5 \cdot 88$ & $1,800^{*}$ & $10 \cdot 6$ \\
\hline$+2^{\prime} 4^{\prime \prime}$ & $28 \cdot 0$ & $2 \cdot 85$ & 8,500 & $24 \cdot 2$ \\
\hline$+0^{\prime} 10^{\prime \prime}$ & $5 \cdot 3$ & 0.56 & 19,300 & $10 \cdot 9$ \\
\hline$-0^{\prime} 8^{\prime \prime}$ & $6 \cdot 7$ & $0 \cdot 74$ & 13,000 & $9 \cdot 48$ \\
\hline$-1^{\prime} 6^{\prime \prime}$ & $13 \cdot 3$ & $1 \cdot 49$ & 26,000 & $38 \cdot 8$ \\
\hline$-4^{\prime} 0^{\prime \prime}$ & $11 \cdot 0$ & 1.32 & 7,900 & $10 \cdot 4$ \\
\hline$-6^{\prime} 2^{\prime \prime}$ & - &. & 0 & - \\
\hline
\end{tabular}

\section{TABLE III.}

Distribution of $B$. balanoides on the Alfred Pier, Port St. Mary. 3Rd July, 1933. Exposure Factor 8.

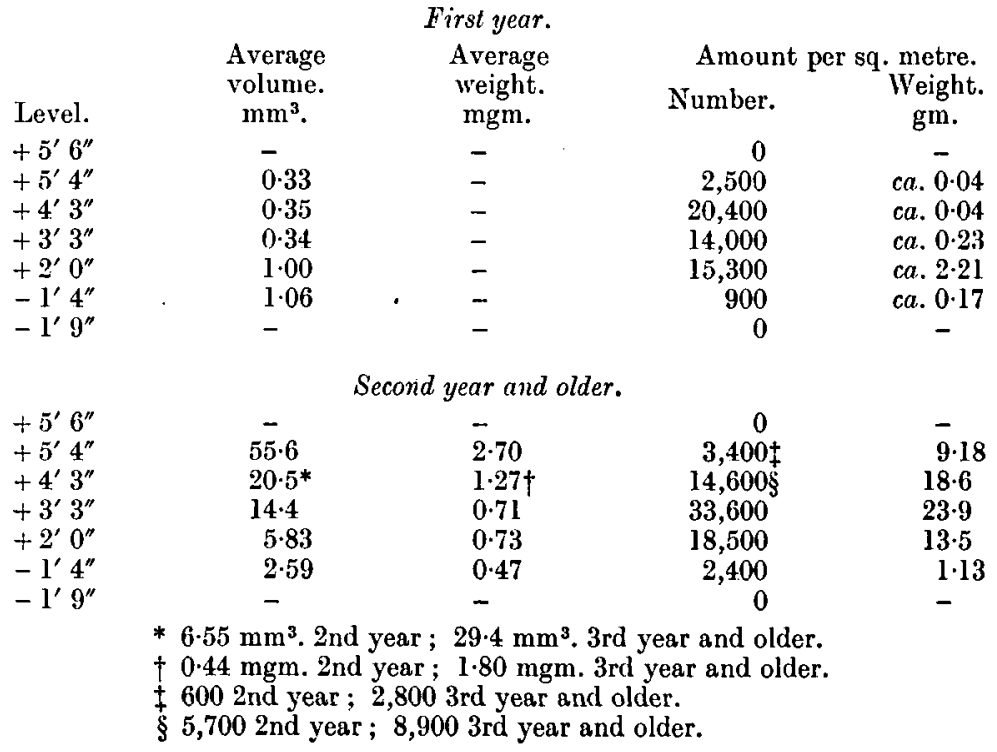




\section{TABLE IV.}

\section{Distribution of $B$. balanoides on the Inner Pier,} Port St. Mary. 12th July, 1933. Exposure Factor 0.

\begin{tabular}{|c|c|c|c|c|}
\hline \multirow[b]{3}{*}{ Level. } & \multicolumn{2}{|c|}{ First year. } & \multirow{2}{*}{\multicolumn{2}{|c|}{ Amount per sq. metre. }} \\
\hline & \multirow{2}{*}{$\begin{array}{c}\text { Average } \\
\text { volume. } \\
\mathrm{mm}^{3} \text {. }\end{array}$} & \multirow{2}{*}{$\begin{array}{c}\text { Average } \\
\text { weight. } \\
\text { mgm. }\end{array}$} & & \\
\hline & & & Number. & $\begin{array}{c}\text { Weight. } \\
\text { gm. }\end{array}$ \\
\hline$+3^{\prime} 8^{\prime \prime}$ & - & - & 0 & - \\
\hline$+2^{\prime} 6^{\prime \prime}$ & $0 \cdot 48$ & - & 5,300 & ca. 0.08 \\
\hline$+1^{\prime} 8^{\prime \prime}$ & 0.61 & 0.02 & 10,300 & 0.21 \\
\hline$-0^{\prime} 4^{\prime \prime}$ & $0 \cdot 81$ & $0 \cdot 07$ & 10,400 & $0 \cdot 73$ \\
\hline$-0^{\prime} 10^{\prime \prime}$ & - & - & 0 & - \\
\hline \multicolumn{5}{|c|}{ Second year and older. } \\
\hline$+3^{\prime} 8^{\prime \prime}$ & - & - & 0 & - \\
\hline$+2^{\prime} 6^{\prime \prime}$ & $2 \cdot 67$ & $0 \cdot 18$ & 500 & $0 \cdot 09$ \\
\hline$+1^{\prime} 8^{\prime \prime}$ & $3 \cdot 78$ & $0 \cdot 32$ & 3,500 & 112 \\
\hline$-0^{\prime} 4^{\prime \prime}$ & $3 \cdot 63$ & $0 \cdot 35$ & 400 & $0 \cdot 14$ \\
\hline$-0^{\prime} 10^{\prime \prime}$ & - & - & 0 & - \\
\hline
\end{tabular}

\section{TABLE V.}

Amounts of Barnacles on a Vertical Strip of Shore One Metre Wide. June-July, 1933. Numbers and Dry Weights of Tissue.

\begin{tabular}{|c|c|c|c|c|c|}
\hline $\begin{array}{l}\text { Locality. } \\
\text { Exposure factor }\end{array}$ & & $\begin{array}{r}\text { Outside } \\
\text { Bradda } \\
\text { Head. } \\
55\end{array}$ & $\begin{array}{c}\text { Dub Reef, } \\
\text { Port } \\
\text { Erin. } \\
30\end{array}$ & $\begin{array}{c}\text { Alfred Pr., } \\
\text { P. St. } \\
\text { Mary. } \\
8\end{array}$ & $\begin{array}{c}\text { Inner Pr., } \\
\text { P. St. } \\
\text { Mary. } \\
0\end{array}$ \\
\hline First Year & $\left\{\begin{array}{l}\text { Number } \\
\text { Weight gm. }\end{array}\right.$ & $\begin{array}{r}142,000 \\
26 \cdot 2\end{array}$ & $\begin{array}{r}265,000 \\
53 \cdot 2\end{array}$ & $\begin{array}{r}23,000 \\
1 \cdot 87\end{array}$ & $\begin{array}{r}11,400 \\
0 \cdot 38\end{array}$ \\
\hline $\begin{array}{l}\text { Secnnd year } \\
\text { and older }\end{array}$ & $\left\{\begin{array}{l}\text { Number } \\
\text { Weight gm. }\end{array}\right.$ & $\begin{array}{r}86,300 \\
516\end{array}$ & $\begin{array}{r}45,600 \\
52 \cdot 9\end{array}$ & $\begin{array}{r}31,000 \\
26 \cdot 0\end{array}$ & $\begin{array}{r}1,800 \\
6 \cdot 65\end{array}$ \\
\hline $\begin{array}{l}\text { Total: } \\
\quad \text { all ages }\end{array}$ & $\left\{\begin{array}{l}\text { Number } \\
\text { Weight gm. }\end{array}\right.$ & $\begin{array}{r}228,000 \\
542\end{array}$ & $\begin{array}{r}311,000 \\
106\end{array}$ & $\begin{array}{r}54,000 \\
27 \cdot 9\end{array}$ & $\begin{array}{r}13,200 \\
7 \cdot 03\end{array}$ \\
\hline
\end{tabular}

